\title{
IMPLEMENTASI PROGRAM PENGEMBANGAN LITERASI BAGI AUD DI KOMUNITAS SEKOLAH LITERASI WADAS KELIR
}

\author{
Triyana ${ }^{1}$, Raden Rachmy Diana ${ }^{2}$ \\ Fakultas Ilmu Tarbiyah dan Keguruan, Universitas Islam Negeri Sunan Kalijaga Yogyakarta ${ }^{1}$, Fakultas Ilmu Sosial \\ dan Humaniora, Universitas Islam Negeri Sunan Kalijaga Yogyakarta ${ }^{2}$ \\ Email: 20204032012@student.uin-suka.ac.id ${ }^{1}$, raden.diana@uin-suka.ac.id ${ }^{2}$ \\ Triyana. Raden Rachmy Diana. (2021). Implementasi Program Pengembangan Literasi Bagi AUD di Komunitas \\ Sekolah Literasi Wadas Kelir. Jurnal Pelita PAUD, 6(1), 41-51. \\ doi: https://doi.org/10.33222/pelitapaud.v6i1.1357
}

Abstrak: Budaya Literasi Masyarakat Indonesia yang tergolong masih sangat rendah sangat miris jika tidak melibatkan banyak pihak untuk bersama meningkatkannya. Gerakan Literasi Nasional (GLN) yang diserukan pemerintah belum juga menunjukkan perubahan yang signifikan di lapangan. Tujuan adanya penelitian ini adalah untuk membentuk budaya literasi melalui gerakan nyata oleh para pegiat literasi, komunitas-komunitas, dan pemerhati masyarakat untuk dapat melihat bagaimana tingkat literasi di masyarakat melalui kegiatan Sekolah Literasi. Penelitian ini menggunakan pendekatan kualitatif dengan tipe fenomenologis. Populasi dalam penelitian ini yaitu seluruh anak dan orangtua sebagai warga sekitar Sekolah Literasi Wadas Kelir. Pengumpulan data dilakukan dengan teknik observasi, wawancara, catatan lapangan, dan dokumentasi. Analisis data menggunakan teknik deskriptif. Penelitian ini menunjukkan bahwa pengembangan literasi di masyarakat melalui rangkaian kegiatan Sekolah Literasi Wadas Kelir memberikan pengaruh yang baik untuk meningkatkan minat baca masyarakat mulai dari anak usia dini hingga orangtua. Sekolah Literasi Wadas Kelir sebuah komunitas literasi yang unggul dan kreatif.

Kata kunci: kegiatan literasi, masyarakat, pengembangan literasi.

Abstract: The Literacy Culture of the Indonesian Society, which is still very low, is very sad if it is left on for too long. The National Literacy Movement (GLN) launched by the government has not shown significant changes in the field. The purpose of this research is to form a literacy culture through real movements by literacy activists, communities, and community observers to be able to see how the literacy level in the community is through the Literacy School activities. This study uses a qualitative approach with a phenomenological type. The population in this study were all children and parents as residents around the Wadas Kelir Literacy School. Data was collected by using observation, interview, field notes, and documentation techniques. Data analysis used descriptive analysis technique. This study shows that literacy development in the community through a series of activities at the Wadas Kelir Literacy School has a good influence on increasing public interest in reading from early childhood to parents. Wadas Kelir Literacy School is an excellent and creative literacy community.

Keywords: literacy activities, community, literacy development. 


\section{PENDAHULUAN}

Pembentukan kepribadian manusia yang unggul dan mandiri merupakan salah satu visi misi bangsa Indonesia. Keberadaan manusia unggul dan mandiri dibuktikan dengan adanya berjalannya proses pendidikan sebagai peran kuat untuk merubah kemoralan peserta didik. Ini sejalan dengan Undang-undang No. 20 tahun 2003 tentang Sisdiknas yang mengatakan bahwa tujuan pendidikan adalah ".. agar menjadi manusia yang beriman dan bertakwa kepada Tuhan Yang Maha Esa, berakhlak mulia, sehat, berilmu, cakap, kreatif, mandiri, dan menjadi warga negara yang demokratis serta bertanggung jawab" (Inanna 2018). Pendidikan juga menjadi tolak ukur kualitas suatu Negara. Pendidikan sendiri membawa ruh kepada manusia untuk dikenalkan dengan perilaku positif dan dibiasakan untuk berperilaku positif. Pada dasarnya kegiatan pendidikan tidak hanya berlangsung di lingkungan sekolah saja namun juga kegiatan di luar sekolah.

Mengapa Indonesia tercatat sebagai negara buta aksara? Pertanyaan ini sering muncul dari berbagai pakar teori literasi dan pemerintahan pendidikan dan kebudayaan ini. Indonesia menjadi sorotan terkait minat baca masyarakat, terlebih pada kalangan siswa kurang. Hal ini disebabkan kemampuan literasinya belum sampai tahapan menangkap makna dari apa yang dibacanya. Dari sinilah, peran pendidikan mengkampanyekan literasi dari 3 sumber yaitu pendidikan keluarga, pendidikan masyarakat, dan pendidikan sekolah.

Gerakan literasi Indonesia secara umum memang tergolong rendah. Penelitian terakhir yang peringkat Indonesia merosot dalam evaluasi Programme for International Student Asessment (PISA). Sejak empat tahun terakhir, posisi Indonesia menurun di semua bidang yang diujikan: membaca, matematika, dan sains. Berdasarkan laporan PISA yang baru rilis, Selasa 3 Desember 2019, skor membaca Indonesia ada di peringkat 72 dari 77 negara, lalu skor matematika ada di peringkat 72 dari 78 negara, dan skor sains ada di peringkat 70 dari 78 negara. Tiga skor itu kompak menurun dari tes PISA 2015. Kala itu, skor membaca Indonesia ada di peringkat
65, skor sains peringkat 64, dan skor matematika peringkat 66 .

Fenomena ini menjadi sebab bagi bangsa ini untuk dapat bersaing dalam dunia akademik internasional. Adapun upaya untuk memberdayakan literasi untuk masyarakat bangsa Indonesia adalah menerapkan peraturan pemerintahan pendidikan dan kebudayaan No. 23 tahun 2015 tentang pertumbuhan budi pekerti. Hal ini diwajibkan untuk peserta didik baik usia dini yang dibacakan buku sampai tingkatan SMA dengan mendesain program Gerakan Literasi Sekolah.

Kemampuan literasi dini tidak terbatas pada kemampuan kognitif saja tetapi merupakan kegiatan sosial-psiko-linguistik yang kompleks dan berpengaruh pada aspek sosial dan kontekstual yang menjadi bagian utuh perkembangan anak. Literasi anak usia dini dapat berkembang dan diperoleh di rumah maupun lingkungan sosialnya (Mardliyah, Siahaan, and Budirahayu 2020). Masyarakat sebagai salah satu lingkungan sosial pendidikan juga mempunyai peran penting dalam mengembangkan budaya literasi pada AUD. Ghoting dan Diaz menuturkan bahwa literasi dini bukan diartikan mengajarkan membaca pada anak, tapi menjadikan anak untuk mencintai membaca, membangun pondasi membaca sedini mungkin untuk membekali anak supaya lebih siap jika dikemudian hari waktunya belajar telah datang (Sari 2017). AUD rupanya memerlukan beragam informasi agar siap menjadi manusia sesungguhnya untuk itu mereka perlu diisi pengetahuan yang banyak. Pengenalan membaca merupakan salah satu cara untuk mendapatkaan informasi karena pada saat mengeja hingga membaca seluruh aspek kejiwaan anak terlibat dan ikut bergerak di dalamnya (Ikawati 2013).

Dari sinilah, Rumah Kreatif Wadas Kelir mempunyai gagasan untuk menyadarkan dan meningkatkan kemampuan membaca masyarakat sekitar dengan cara mendirikan Sekolah Literasi Wadas Kelir. Sekolah Literasi Wadas Kelir menjadi salah satu inovasi yang menjembatani masyarakat untuk memutus rantai buta aksara sejak dini.

Kebaharuan dari penelitian ini ialah terletak pada ruh yang dibangundan inovasi pada pembelajaran yang dilakukan di dalamnya. 
Anak-anak dikenalkan dengan literasi tidak hanya literasi dalam arti membaca, namun anak-anak dikenalkan dengan berbagai permainan tradisional, dongeng mancanegara, terjemahan novel luar negeri, retelling cerita rakyat, bermain peran, kisah sehari-hari, wisata literasi, dan berangkat dari kegiatan ini, Sekolah Literasi Wadas Kelir menjadi pusat pembelajaran bagi anak di luar pendidikan formal yang menyenangkan.

Mendesain Sekolah Literasi telah mampu membawa masyarakat memiliki ketertarikan dengan kegiatan membaca sejak dini. Ketertarikan inilah yang menggerakkan setiap individu masyarakat untuk terus melakukan kegiatan literasi dasar yaitu membaca. Membaca merupakan salah satu kemampuan anak memahami bacaan atau teks pada buku untuk mengungkapkan suatu imajinasi terhadap bacaannya. Pada dasarnya, pada setiap proses pembelajaran tentang membaca anak tidak diharuskan untuk dapat membaca, akan tetapi pembelajaran pada AUD semata untuk menumbuhkan minat membaca pada AUD dimulai dengan mengenalkan anak pada huruf-huruf merangkainya menjadi kata-kata lalu membentuk suatu kalimat (Latifah, 2019). Kebanyakan anak usia TK berada pada "gerbang" menjadi pembaca. Pada usia ini anak pada umumnya membaca dengan melihat tulisan, tetapi anak sering bergantung pada ingatan mengenai cerita dan gambar (Lestari 2019). Adapun kegiatan yang biasa dilakukan yaitu, belajar kognitif, belajar bahasa, belajar performa pantomime, performa dongeng, dan performa tari. Semua kegiatan ini muaranya anak-anak untuk membaca dan menulis dengan kebiasaan meminjam buku yang sudah disuplai oleh Taman Bacaan Masyarakat Wadas Kelir.

Hal ini menjadi penilaian kemampuan membaca yang dilakukan oleh Programme for International Student Assessment (PISA) menghasilkan bahwasanya Indonesia merupakan Negara dengan tingkat kemampuan membaca yang rendah. Berdasarkan penilaian PISA pada tahun 2000 menyatakan bahwa Indonesia menduduki Negara dengan kemampuan membaca terendah ketiga dari negara-negara yang dinilai dan hanya mendapatkan 371 skor. Tahun 2003 mendapatkan 383 skor. Tahun 2006 mendapatkan 393 skor. Tahun 2009 mendapatkan 402 skor dan pada tahun 2012 dan 2015 pun sama hasilnya bahwa Indonesia masih memiliki kemampuan membaca yang rendah (Abidin, Yunus, Tita Mulyati 2018).

Berangkat dari data yang ada, sangat miris jika hal tersebut terus didiamkan. Untuk itu, melalui Teras Baca Wadas Kelir masyarakat diajak, diperkenalkan bahkan dibiasakan sejak dini untuk melakukan kegiatan literasi dasar yaitu membaca. Kegiatan membaca di Taman Baca Masyarakat Wadas Kelir diharapkan mampu menjadi pemantik pemberantasan buta aksara sejak dini dalam masyarakat.

Mengingat pentingnya kebiasaan membaca yang harus dilakukan sejak dini, Taman Baca Masyarakat Wadas Kelir berinisiatif mendirikan Sekolah Literasi bagi AUD hingga SD. Berdirinya Sekolah Literasi ini sejalan dengan pencanangan gerakan literasi PBB dan fakta mengenai peran penting literasi yang dapat membangun kemajuan Negara, dari sini Indonesia membuat pencanangan Gerakan Literasi Nasional (GLN), yaitu gerakan bersama untuk membiasakan melakukan aktifitas membaca, berfikir, dan menulis dalam konteks keluarga, masyarakat, dan sekolah (Suwandi 2019).

Taman Baca Masyarakat Wadas kelir yang berada di Komunitas Rumah Kreatif Wadas Kelir fokus pada pembelajaran kreatif yang di dalamnya terdapat pembiasaan mendengarkan dongeng dan diakhiri dengan ujian tertulis yang dilakukan oleh Pak Guru Heru Kurniawan selaku Pimpinan Rumah Kreatif Wadas Kelir. Tidak berhenti pada dongeng saja, beliau memperkenalkan anak-anak tentang retelling cerita rakyat Jawa Tengah dan editing clinic beberapa cerita yang tanpa kita sadari menggambarkan perilaku negatif pada lakon cerita, misal cerita Kancil Mencuri Timun di editing menjadi Kancil tidak suka mencuri Timun. Inilah yang membawa ketertarikan sendiri bagi anak-anak.

Sekolah Literasi Wadas Kelir ini mempunyai pembelajaran kreatif yang bertujuan mewujudkan anak-anak yang bermutu, yaitu anak-anak yang berkualitas, cerdas, tanggap, dan berkarakter. Komunitas ini menjadi salah satu komunitas yang dapat menguatkan keterampilan anak untuk membaca, menulis, dan tanggap menganalisis beberapa cerita yang disampaikan Pak Guru Heru (Anisatul Laely 2019).

Pembelajaran Literasi dengan pembiasaan mendengarkan dongeng yang diakhiri dengan 
ujian di Sekolah Literasi Wadas Kelir dilaksanakan setiap Senin sampai Sabtu. Melalui cara inilah anak-anak mulai tertarik untuk melakukan aktifitas membaca intens di luar kegiatan sekolah, bahkan sebagian dari mereka mulai menunjukkan sikap percaya diri untuk tampil di media masa youtube mengulas sebuah buku Dongeng Anak dari Kemendikbud. Pak Guru Heru sebagai pelopor pendiri Sekolah Literasi Wadas Kelir menyatakan bahwa kegiatan didasari melihat anak-anak tidak melakukan kegiatan pada sore hari.

Beliau berasumsi bahwa rangkaian kegiatan Sekolah Literasi yang diawali dengan bercerita dan anak-anak mendengarkan, mampu menanamkan file kehidupan pada anak sedini mungkin dengan harapan setelah mereka dewasa dapat merecall/ memanggil kembali file-file lalu untuk diaplikasikan sebagaimana dulu mereka diperlakukan saat kecil.

Penyelenggaraan Sekolah Literasi Wadas Kelir dikemas dalam bentuk sesederhana mungkin. Kegiatan Sekolah Literasi ini di luar kegiatan sekolah, artinya kegiatan ini masuk ke dalam Literasi Masyarakat. Bermula dari Sekolah Literasi anak-anak mulai sadar dan menanggapi serius akan pentingnya membaca, menulis, hingga perlunya percaya diri di hadapan oranglain.

Inti dari gerakan Literasi pada dasarnya adalah menggerakkan manusia untuk mempunyai minat membaca dan menulis. Sekolah Literasi Wadas Kelir telah memberikan kontribusi untuk anak bangsa melalui kegiatan membaca, bermain, berlatih acting, mendongeng hingga sampai ke tahap evaluasi pembelajaran selama seminggu sekali. Dari sinilah, peneliti tertarik untuk melakukan penelitian di Sekolah Literasi Wadas Kelir. Penelitian ini bertujuan untuk dapat melihat bagaimana tingkat literasi di masyarakat melalui kegiatan Sekolah Literasi.

\section{Konsep Literasi Masyarakat pada Interaksi Anak}

Minat baca masih menjadi persoalan dan masalah serius bangsa ini, hal ini cukup memprihatinkan dan merisaukan. Rendahnya minat baca masyarakat berdampak serius pada rendahnya kemampuan membaca masyarakat. Terdapat hubungan linear antara minat baca masyarakat (reading interest) dengan kebiasaan membaca (reading habit) dan kemampuan membaca (reading ability). Maksudnya adalah rendahnya minat baca masyarakat menjadi kebiasaan membaca rendah, dan kebiasaan membaca rendah ini menjadikan kemampuan membaca rendah (Suwandi 2019).

Tjalla, Kharizni, Irianto, dan Febriani dalam Kurniawan dan Supriyono menyatakan bahwa rendahnya kegiatan membaca masyarakat atau problematika gerakan literasi kurang diminati masyarakat disebabkan oleh kenyataan tingkat literasi masyarakat yang rendah dan mereka berpersepsi bahwa literasi tidak dapat mendatangkan keuntungan yang dapat dirasakan kebermanfaatannya secara langsung. Dua persoalan ini menyebabkan perilaku sosial masyarakat kita yang tidak peduli dengan literasi serta tidak mau menggerakkan literasi sebagai salah satu cara memutus mata rantai buta aksara dalam lingkungan masyarakat (Kurniawan 2019).

Persepsi inilah yang perlu diubah pola pikirnya, dikutip dari laman Kumparan, Syarif Yunus mengatakan bahwa tidak akan ada Negara di dunia ini dengan sumber daya manusia yang kompetitif bila tidak didukung dengan budaya literasi masyarakatnya yang berkualitas. Masih menjadi tugas berat para pegiat literasi persoalan budaya literasi di Indonesia akan dimulai dari mana, dari taman bacaan kah, dari perpustakaan kah, atau bahkan akses buku bacaan yang harus diperluas dan merata. Padahal, Gerakan Literasi Nasional (GLN) juga sudah dicanangkan oleh pemerintah (Yunus 2020).

Di era kepemimpinan Soeharto sejarah telah mencatat bahwa adda gerakan besar-besaran, yakni Bebas 3 BUTA: Bebas Buta Aksara, Bebas Buta Angka, dan Bebas Buta Bahasa Indonesia. Pada tahun-tahun selanjutnya Megawati Soekarno Putri juga memperlihatkan kepeduliannya akan literasi upaya peningkatan budaya baca masyarakat dengan meresmikan secara serentak sebanyak 50 rumah baca yang tersebar di seluruh Indonesia pada 5 Maret 2004 (Suwandi 2019). Menumbuhkan minat baca merupakan langkah awal dari upaya menciptakan budaya baca masyarakat. Menciptakan dan mengembangkan minat baca masyarakat akan terwujud jika semua pihak baik dari pemerintah, kalangan swasta, pustakawan, 
dunia pendidikan, orang tua, komunitas, dan lapisan masyarakat lainnya berusaha untuk saling melengkapi dari apa yang kurang dan berusaha semaksimal mungkin melakukan kegiatan gemar literasi untuk mencapai tujuan bersama yaitu mencerdaskan masyarakat. Berdasarkan UU RI No. 43 Tahun 2007 Pasal 48 tentang Pembudayaan Kegemaran Membaca dilakukan melalui keluarga, pendidikan, dan masyarakat. Pembudayaan kegemaran membaca pada masyarakat sebagaimana pada ayat (1) dilakukan melalui penyediaan sarana perpustakaan di tempattempat umum yang mudah terjangkau, murah, dan bermutu (Friantary 2019).

Dari sinilah, dapat ditarik benang merah bahwa mau tidak mau tradisi baca dan budaya literasi masyarakat sangat penting untuk dibangkitkan dan diadakan oleh komunitaskomunitas maupun para pegiat literasi dan pemerhati lingkungan. Mungkin harus dengan sedikit sentuhan tradisi baca dengan paksaan untuk menjadi sebuah kebiasaan.

Sentuhan tradisi baca pada AUD hendaklah dikemas dengan cara yang menyenangkan, seperti mendongeng. Ariani dan Hariyono mengungkapkan bahwa mendongeng merupakan teknik yang bisa membuat anak belajar tanpa menggurui mereka. Berdasarkan beberapa penelitian, metode mendongeng memang cocok diterapkan untuk anak-anak (Yansyah, Hamidah, and Ariani 2021). Nyatanya anak selalu menikmati setiap kali dongeng dimulai, memperhatikan seksama cerita dongeng, menjawab pertanyaan, jawaban berantai, mengilustrasikan tokoh di dalam cerita, memperagarakan tokoh dalam cerita, serta mulai mencontoh karakter baik dalam cerita untuk diaplikasikan dalam kegiatan sehari-hari.

\section{METODE PENELITIAN \\ Jenis Penelitian}

Penelitian ini adalah penelitian lapangan (field research), yakni mengadakan pengamatan langsung dengan objek yang diteliti dan dilakukan dengan mengumpulkan data yang ditemukan di lapangan. Penelitian ini merupakan penelitian kualitatif. Menurut Zuriah dalam Anisatul menyatakan penelitian kualitatif adalah prosedur penelitian yang menghasilkan data deskriptif berupa kata-kata tertulis maupun lisan dari orang-orang dan perilaku yang dapat diamati. Menurut Sulistyo dalam Titi Anisatul menyatakan penelitian bertujuan memperoleh gambaran seutuhnya mengenai suatu hal menurut pandangan manusia yang diteliti dan juga data-data empiris yang mendukung penelitian (Laely 2019).

\section{Waktu dan Tempat Penelitian}

Lokasi penelitian, yaitu Komunitas Rumah Kreatif Wadas Kelir yang beralamat di Jalan Wadas Kelir RT 07/ RW 05 Kelurahan Karangklesem Purwokerto Selatan, Banyumas, Jawa Tengah melalui kegiatan Sekolah Literasi Wadas Kelir pada pukul 15.30-17.30 setiap hari, kecuali Minggu libur.

\section{Subjek Penelitian}

Objek penelitian ini yaitu pengembangan literasi masyarakat yang dilakukan sejak dini melalui Sekolah Literasi Wadas Kelir. Populasi dalam penelitian ini, yaitu seluruh anak dan orangtua yang juga warga sekitar di Sekolah Literasi Wadas Kelir.

\section{Prosedur}

Pengumpulan data dilakukan dengan teknik observasi, wawancara, catatan lapangan, dan dokumentasi. Data dari keempat teknik ini dianalisis kembali dan di cross check ntuk mendapatkan data yang valid dan akurat.

Data, Intrumen, Teknik Pengumpulan Data, dan Teknik Analisis Data

Analisis data menggunakan analisis deskriptif. Data yang telah terkumpul kemudian dianalisis menggunakan teknik analisis data model Miles dan Huberman dengan langkahlangkah analisis: reduksi data, display data dan verifikasi data. Pada reduksi data penulis memilah dan memilih data yang bisa menjawab rumusan masalah. Pada display data penulis menyajikan data untuk menjawab rumusan masalah. Kemudian pada tahap verifikasi penulis membuat opini dan kesimpulan untuk menjawab rumusan masalah (Wigati and Wiyani 2020).

\section{HASIL PENELITIAN PEMBAHASAN}

Sekolah Literasi Wadas Kelir

Lembaga pendidikan merupakan pelaksana pendidikan yang menjadi acuan untuk bagaimana nantinya perkembangan dan pertumbuhan generasi bangsa di masa depan 
(Samiaji, Hidayat, and Najah 2021). Lembaga pendidikan mempunyai dedikasi tinggi dalam hal mencerdaskan bangsa di bidang akademik. Yayasan Rumah Kreatif Wadas Kelir yang di dalamnya terdapat Komunitas Rumah Kreatif Wadas Kelir mempunyai kegiatan Sekolah Literasi Wadas Kelir yang menjadi salah satu unit kegiatan yang sudah berjalan sejak 2013. Sekolah Literasi Wadas Kelir merupakan sebuah kegiatan belajar dan bermain yang diadakan oleh Komunitas Anak Rumah Kreatif Wadas Kelir untuk membekali keterampilan hidup yang lebih pada anak dalam berbagai bidang sejak dini (Anisatul Laely 2019).

Komunitas Rumah Kreatif Wadas Kelir yang beralamat di Jalan Wadas Kelir RT 07/ RW 05 Kelurahan Karangklesem Purwokerto Selatan, Banyumas melalui kegiatan Sekolah Literasi Wadas Kelir menyediakan tiga kelas bermain, diantaranya kelas bermain sains, kelas bermain bahasa, dan kelas bermain seni. Setiap Senin sampai Sabtu anak-anak berkumpul di PBM (Pusat Belajar Masyarakat) Wadas Kelir untuk belajar dan bermain bersama.

Pembelajaran Literasi dari Pak Guru Heru ini sebagai pembukaan belajar dengan permainan kata dan huruf, kegiatan inti dengan mendengarkan Pak Guru Heru mendongeng, ditutup dengan ujian harian dari cerita pada hari itu, dan diakhiri dengan pelaksanaan ujian pada Sabtu di setiap minggunya. Pembelajaran dengan mendengarkan hingga ujian inilah anak-anak mulai dikenalkan dengan budaya membaca yang dimulai dengan membaca cerita rakyat dan cerita dongeng. Salah satu kegiatan yang dapat dilakukan dalam mengembangkan keterampilan berbicara anak adalah dengan menerapkan metode bercerita pada anak. Metode bercerita merupakan salah satu metode pembelajaran yang digunakan di dalam pendidikan anak usia dini (Fitriani dkk 2019). Penyampaian cerita yang menghadirkan tokoh binatang sebagai peran utamanya sangat menarik bagi anak-anak. Terlebih intonasi pada saat bercerita, pemunculan tokoh-tokoh yang unik, penampakan emosi, peniruan suara sesuai tokoh, hingga anak-anak disuruh untuk melakukan peragaan suara tokoh dan kegiatan yang dilakukan tokoh membuat anak- anak semakin bersemangat bahkan anak mampu mengingat setiap kosa kata dalam cerita (Majid 2013).

Pak Guru menuturkan cerita yang menyenangkan itu cerita yang menghadirkan tokoh utama adalah seekor binatang, karena pada dasarnya dunia anak itu sangat tertarik dengan dunia binatang, tinggal bagaimana cara kita menyampaikannya.Selain itu juga perlu diketahui, anak-anak akan merasa sangat bosan dan jenuh ketika sebuah cerita berakhir dengan percakapan atau isi cerita dengan sebuah nasehat. Anak-anak akan lebih tertarik dengan cerita yang membuat penasaran, jadi anak disuruh untuk menyebutkan sifat tokoh dalam cerita. Disinilah terjadi proses analisis kritis yang dilakukan anak dimulai dengan hal yang sederhana.

Berikut beberapa kegiatan yang dilakukan untuk meningkatkan minat baca, menulis, dan berfikir anak:

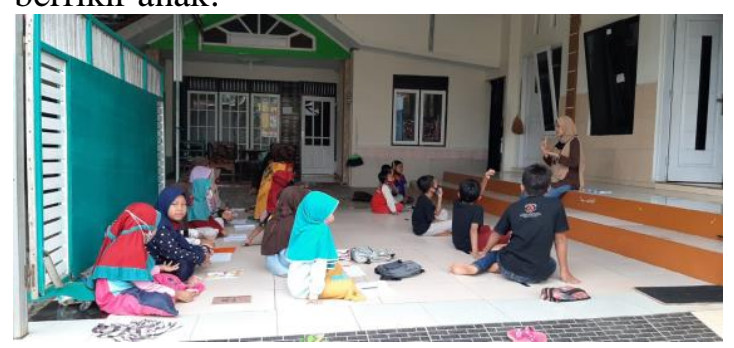

Gambar 1. Anak-anak melakukan permainan kata dan angka dengan dipandu turor/ pengajar Sekolah Literasi

Pertama, Permainan Kata dan Angka. Teori membaca yang digagas Montesori memperkenalkan permainan membaca dimulai dari unsur huruf (Dodi Ahmad Haerudin, 2018). Dengan permulan pengenalan huruf anak nantinya akan mampu untuk merangkau sebuah kata bahkan kalimat. Permainan kata yang digagas ialah anak-anak dipandu pengajar Sekolah Literasi untuk menyebutkan dan menyambungkan kata selanjutnya dengan awalan huruf terakhir dari kata yang disebutkan temannya. Sebagai contoh kata pertama: BukU_UdanG_Gandum_MakaN_NasI IkaN_Nila_AngsA dan seterusnya.

Dari sinilah anak diajarkan untuk berfikir cepat dan kreatif menemukan kata benda, kata sifat atau lainnya dalam waktu yang singkat. Permainan angka, PAUD adalah salah satu bentuk penyelenggaraan yang menitik beratkan pada peletakan dasar kearah 
pertumbuhan fisik, kecerdasan, sosial, emosional, bahasa dan kognitif. Salah satu aspek dalam pengembangan kognitif adalah mengenal angka (Anggrayni and Sari 2019). Permainan angka yang digagas ialah anakanak dengan dipandu pengajar Sekolah Literasi menyebutkan 2 digit angka terakhir dari temannya untuk dilanjutkan. Misalkan: 1234_ 3456_ 5678_ 7890_ 9012_ 1291

$9123 \_2345 \_4572$ dan seterusnya. Selain dilatih berfikir cepat dan tepat, permainan ini juga melatih anak untuk konsentrasi penuh.

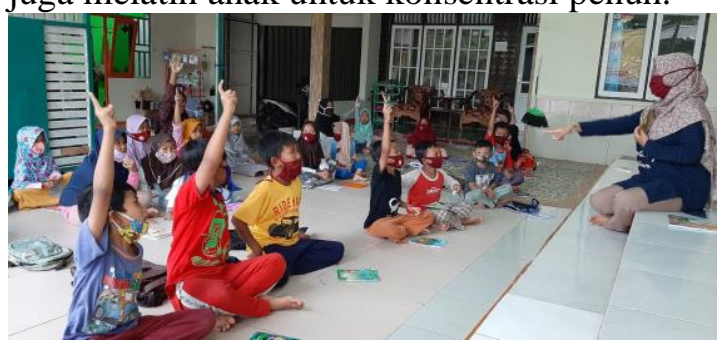

Gambar 2. Cek tingkat konsentrasi anak dipandu turor/ pengajar Sekolah Literasi

Kedua, melatih Konsentrasi. Sebagai pemanasan sebelum kelas dimulai, alangkah baiknya jika anak-anak dicek konsentrasinya. Jangan sampai mereka hanya mendatangkan raganya saja tanpa mendatangkan pikirannya selama belajar. Banyak sekali cara yang dilakukan untuk melatih konsentrasi anak. Salah satu yang dilakukan oleh pengajar Sekolah Literasi ialah dengan menyebutkan angka 1, 2, 3, 4, dan 5 dengan menggunakan simbol 5 jari tangan.

Misal: angka 1 disimbolkan dengan jari telunjuk. Angka 2 disimbolkan dengan jari kelingking dan jari manis. Angka 3 disimbolkan dengan jari kelingking, telunjuk, dan jempol, angka 4 disimbolkan dengan jari jempol, telunjuk, jari tengah, dan jari manis, dan terakhir angka 5 disimbolkan dengan kelima jari tangannya. Lakukan kegiatan ini dengan klu permainan semisal, 1_3_5, 5_4_1, 3_5_2, 4_3_1 dan seterusnya mulai dari perlahan hingga cepat sampai anak-anak menunjukkan konsentrasinya dengan bukti tidak ada yang salah selama permainan dilakukan.

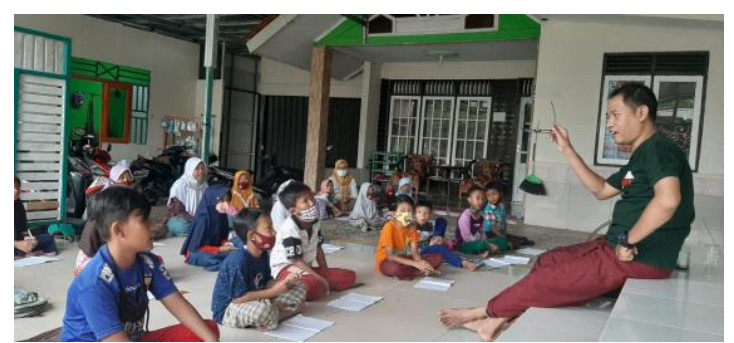

Gambar 3. Anak-anak mendengarkan Pak Guru Heru mendongeng

Ketiga, mendengarkan Dongeng. Cerita sebagai media yang tepat untuk memberikan suatu pelajaran, karena siswa dapat merasakan atau menghayati sosok tokoh dalam cerita. Melalui bercerita dapat memberikan pengalaman belajar dan sebuah informasi mengenai pengetahuan, nilai-nilai moral, dan lain sebagainya (Fitriani, 2019). Cerita yang dibawakan Pak Guru Heru merupakan kegiatan inti, anak-anak mendengarkan dongeng yang disampaikan oleh Pak Guru Heru selama sekitar 20-30 menit. Tidak hanya mendongeng biasanya Pak Guru Heru juga melakukan Retelling Cerita Rakyat hingga Editing Clinic Cerita yang selama ini tidak kita sadari jika cerita-cerita tersebut disampaikan ke anak secara mentah akan berpengaruh kepada kebiasaan anak yang kurang baik.

Di sinilah, point menarik bagi anak, Pak Guru Heru mengedit cerita Kancil Suka Mencuri Timun Menjadi Kancil Tidak Suka Mencuri Timun dan beberapa cerita baik mengenai Kancil. Untuk Retelling Cerita Rakyat sebagai contoh ialah Timun Mas. Cerita ini biasanya hanya berakhir pada kemenangan Timun Mas yang berakhir mengalahkan Raksasa dan Timun Mas hidup bahagia dengan Mbok Rondo. Namun, di Sekolah Literasi Wadas Kelir cerita ini di Retelling dengan akhiran Timun Mas dan Mbok Rondo meras menyesal dan merasa telah mengkhianati Raksasa. Sebagai gantinya mereka merawat anak Raksasa dengan baik dan hidup berdampingan.

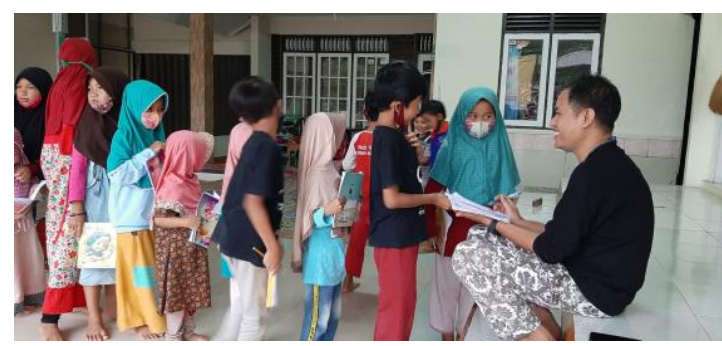


Gambar 4. Antusias penilaian anak pada evaluasi harian yang dipandu langsung oleh Pak Guru Heru dari mendengarkan dongeng dan retelling cerita rakyat pada hari itu

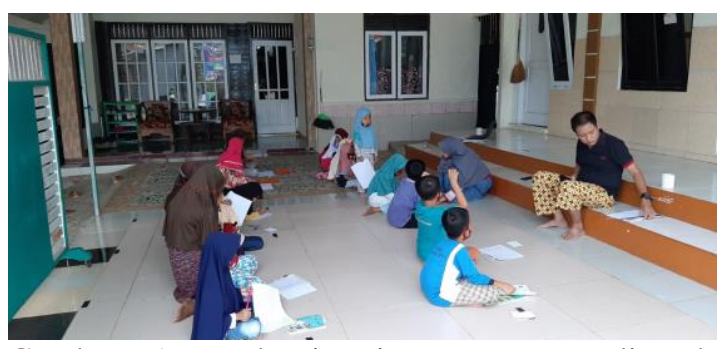

Gambar 5. Evaluasi mingguan yang dipandu langsung oleh Pak Guru Heru turor/ pengajar Sekolah Literasi dari mendengarkan dongeng dan retelling cerita rakyat selama satu minggu

Keempat, analisis dan evaluasi. Tidak hanya berhenti pada menyimak dan mendengarkan dongeng dari Pak Guru Heru, diakhir dari mendengarkan anak diajak untuk merecall kembali cerita yang telah disampaikan. Evaluasi ini berupa ulangan sesaat setelah selesai bercerita. Anak-anak menuliskan angka 1-10 dan aka nada 10 pertanyaan yang diajukan untuk dijawab dalam waktu yang singkat.

Terdapat 2 evaluasi dalam Sekolah Literasi Wadas Kelir, yaitu evaluasi harian seperti di atas dan evaluasi mingguan yang dilaksanakan setiap Sabtu. Pada Sabtu anakanak akan mengejakan beberapa pertanyaan di lembar jawab dengan materi 5 cerita dan dongeng yang disampaikan dari Senin-Jumat pada satu minggu itu. Selain itu, anak juga diajak untuk menganalisis pesan moral dan sifat yang dilakukan tokoh dalam cerita. Hal lain yang dilakukan ialah anak ikut memperagakan perilaku tokoh, suara tokoh bahkan gerakan tokoh dalam cerita.

Sebagai contoh ialah "Kukuruyuuuk...Akulah Ayam Cindelaras, Rumahku Hutan Belantara, Atapnya Daun Kelapa, Ayahku Raden Putra, Kerajaanku di Jenggala, Kukuruyuuuk." Dari sinilah, Pak Guru Heru mengenalkan kepada anak sebuah cerita legendaris, yang mungkin saat ini sudah dilupakan. Pada evaluasi ini anak akan diberikan reward dari pengajar berupa bintang. Bintang walaupun itu hanya berupa oretan pena di buku anak, namun memberikan kesan yang sangat luar biasa untuk anak.

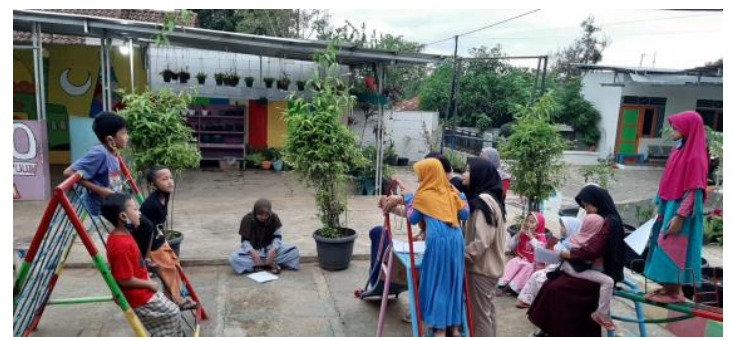

Gambar 6. Persiapan anak untuk shooting sebagai salah satu cara melatih percaya diri anak dan salah satu teknik analisis diri anak

Untuk analisis ialah anak-anak diajarkan untuk melatih percaya diri mereka dengan menganalisis isi buku cerita dan menceritakannya kembali dengan diunggah di Youtube dengan kata lain shooting atau bermain peran. Hal ini bertujuan supaya anak juga melek literasi digital. Terkadang anak percaya diri hanya pada keluarganya saja "jago kandang", namun jika dihadapkan dengan khalayak ramai anak identik diam tidak tau mau berbuat apa.

Dari keempat kegiatan yang ada di Sekolah Literasi ini diharapkan dapat tersampaikan ke anak dengan baik. Sehingga membekas dan terngiang di dalam benak anak hingga ia dewasa. Karena yang diharapkan oleh para tutor ialah, bukan anak cerdas untuk saat ini, namun anak mampu mengingatnya saat dewasa nanti. Ketika ia sudah dewasa, mampu mendatangkan ingatan-ingatan cerita masa kecilnya dan dicertakan kembali kepada anakanak dengan gaya sesuai dengan zamannya.

\section{Pengembangan Literasi Masyarakat Melalui Sekolah Literasi}

Membaca dan menulis merupakan ruh dari gerakan literasi, walaupun dewasa ini literasi diartikan lebih luas lagi, ada literasi teknologi, literasi media dan lainnya. Telah dipaparkan sebelumnya gerakan budaya literasi telah dicanangkan melalui Gerakan Literasi Nasional (GLN). Selain itu juga Pengelolaan Taman Bacaan masyarakat, organisasi perpustakaan, gerakan pemasyarakatan minat baca di berbagai provinsi berupaya menciptakan berbagai program kreatif seperti perpustakaan masuk desa. Perpustakaan bergerak masuk dimana-mana, diantaranya motor pustaka, bemo pustaka, angkot pustaka, perahu pustaka, bahkan becak pustaka (Ekawati and Wijayanti 2017). Diharapkan mampu menyadarkan masyarakat akan budaya membaca dan menulis. 
Komunitas Rumah Kreatif Wadas Kelir menanggapi gerakan budaya literasi yang dicanangkan pemerintah dengan beberapa kegiatan di dalamnya:

Taman Baca Masyarakat, TBM yang berjalan semakin baik seiring berjalannya waktu dan kesadaran masyarakat akan pendidikan, lebih sederhananya ialah membaca dan menulis. Taman bacaan masyarakat adalah lembaga pembudayaan kegemaran membaca masyarakat yang

Menyediakan dan memberikan layanan di bidang bahan bacaan, berupa: buku, majalah, tabloid, koran, komik, dan bahan multimedia lain, yang dilengkapi dengan ruangan untuk membaca, diskusi, bedah buku, menulis, dan kegiatan literasi lainnya, dan didukung oleh pengelola yang berperan sebagai motivator (Saepudin, Sukaesih, and Rusmana 2017). Ratusan buku disediakan untuk masyarakat dari anak-anak, remaja, dewasa, ibu rumah tangga, hingga kakek nenek yang sudah bercucu. Fasilitas ini disediakan secara gratis untuk dipinjam masyarakat baik sekedar dibaca di tempat hingga dibawa pulang selama seminggu. Buku-buku yang ditawarkan mulai dari dongeng untuk anak, cerita rakyat, novel luar dan dalam negeri, buku pendidikan, skripsi, fiksi non fiksi, biografi, sejarah, dan beberapa buku keilmuan umum.

Sekolah Literasi, menggagas untuk memberikan pembiasaan belajar sambil bermain yang menyenangkan. Kemampuan dasar yang harus dikembangkan di Sekolah Literasi Wadas Kelir yaitu, keterampilan menyimak dan mendengarkan, keterampilan berbicara mengungkapkan pendapat, keterampilan membaca, serta keterampilan menulis (Anisatul Laely 2019). Sekolah Literasi menerapkan keempat keterampilan tersebut pada anak-anak melalui pembelajaran kreatif mendengarkan yang diakhiri dengan ujian. Kegiatan yang dilakukan dan diulang pada setiap harinya di Sekolah Literasi Wadas Kelir efektif dilakukan.

Hal ini membawa perubahan yang signifikan, anak bahkan mulai bisa mengulas isi buku cerita, tampil percaya diri masuk youtube, percaya diri mengikuti lomba, dan poin penting ialah orangtua anak mulai sadar bahwa pendidikan di luar sekolah mempunyai peran yang sangat penting. Orangtua mulai terbiasa mengikuti pola keseharian anak untuk sekedar membacakan cerita atau dongeng yang mereka bawa pulang atau sekedar mendampingi anak selama membaca. Dari sini mau tidak mau orangtua juga dituntut untuk membaca lebih dari buku yang anak baca.

\section{SIMPULAN}

Taman Baca Masyarakat Wadas Kelir memberikan kontribusi besar pada lingkungan masyarakat akan budaya literasi dini selain unsur keluarga dan sekolah. Ada banyak cara untuk menyadarkan dan membudayakan masyarakat giat membaca. Salah satunya ialah peran Komunitas Rumah Kreatif Wadas Kelir yang mendirikan Sekolah Literasi yang memfasilitasi anak untuk belajar sambil bermain dengan salah satu kegiatannya adalan mendengarkan dan menganalisis dongeng.

Kegiatan program pengembangan literasi AUD yang dilaksanakan diantaranya permainan kata dan angka, pelatihan konsentrasi anak, mendengarkan dongeng, serta evaluasi berupa penilaian harian dan mingguan. Program pengembangan literasi lain yang dilakukan ialah dengan melakukan permainan tradisional yang disisipkan unsur literasi, wisata literasi, dan bermain peran, Berangkat dari kegiatan ini, Sekolah Literasi Wadas Kelir menjadi pusat literasi yang menyennagkan.

\section{DAFTAR PUSTAKA}

Abidin, Yunus, Tita Mulyati, dan Hana Yunansah. 2018. Pembelajaran Literasi: Strategi Meningkatkan Kemampuan Literasi Matematika, Sains, Membaca, Dan Menulis. Jakarta: Bumi Aksara.

Anggrayni, M., and Ayu Mustika Sari. 2019. "Peningkatan Kemampuan Mengenal Angka Dengan Menggunakan Media Papan Flanel." Jurnal Pelita PAUD 4 (1): 22-28. https://doi.org/10.33222/PELITAPAUD.V4I 1.823 .

Anisatul Laely, Titi. 2019. Penguatan Keterampilan Berbahasa Krama Inggil Melalui Kegiatan Sekolah Literasi Wadas Kelir (Prosiding Seminar Hasil Penelitian Kebahasaan). Semarang: Balai Bahasa Jawa Tengah, Badan Pengembangan Bahasa dan Perbukuan, dan Kementrian Pendidikan dan Kebudayaan. 
Damaianti, Vismaia S. 2020. "Penilaian Implementasi Gerakan Literasi Di Jawa Barat Assessment of Literacy Movement Implementation in West Java." Jurnal Pendidikan Bahasa Dan Sastra 20 (2): 21120.

Ekawati, Mursia, and Asri Wijayanti. 2017. "Peran Media Massa Meningkatkan Daya Literasi Masyarakat Di Era Global.” Pibsi Xxxix, no. November: 736-43.

Fitriani, Agisty, Nahrowi Adjie, Finita Dewi, and Risty Risty Justicia. 2019. "Studi Kasus Perkembangan Keterampilan Berbicara Anak Usia Dini Melalui Penerapan Metode Bercerita." Jurnal Pelita PAUD 4 (1): 2937.

https://doi.org/10.33222/PELITAPAUD.V4I 1.825 .

Friantary, Heny. 2019. "Budaya Membaca sebagai Upaya Peningkatan Kualitas Hidup Masyarakat." Disastra: Jurnal Pendidikan Bahasa Dan Sastra Indonesia 1 (1): 66-70. https://doi.org/10.29300/DISASTRA.V1I1.1 485.

Ikawati, Erna. 2013. "Upaya Meningkatkan Minat Membaca pada Anak Usia Dini." Logaritma: Jurnal Ilmu-Ilmu Pendidikan Dan Sains 1 (02). https://doi.org/10.24952/LOGARITMA.V1I 02.219 .

Inanna. 2018. "Peran Pendidikan Dalam Membangun Karakter Bangsa Yang Bermoral." JEKPEND: Jurnal Ekonomi Dan Pendidikan 1 (1): 27-33. https://doi.org/10.26858/jekpend.v1i1.5057.

Kurniawan, Heru dan Supriyono. 2019. Pengembangan Litera-Preneur Buku Bacaan Anak Di Komunitas Wadas Kelir Purwokerto (Prosiding Seminar Hasil Penelitian Kebahasaan). Semarang: Balai Bahasa Jawa Tengah, Badan Pengembangan Bahasa dan Perbukuan, dan Kementrian Pendidikan dan Kebudayaan.

Lestari, Ni Gusti Ayu Made Yeni. 2019. "Stimulasi Membaca Permulaan Anak Usia Dini." Pratama Widya: Jurnal Pendidikan Anak Usia Dini 3 (2). https://doi.org/10.25078/PW.V3I2.731.

Majid, Abdul Aziz Abdul. 2013. Mendidik Dengan Cerita. Bandung: Rosdakarya Offset.
Mardliyah, Sjafiatul, Hotman Siahaan, and Tuti Budirahayu. 2020. "Pengembangan Literasi Dini Melalui Kerjasama Keluarga Dan Sekolah Di Taman Anak Sanggar Anak Alam Yogyakarta." Jurnal Obsesi : Jurnal Pendidikan Anak Usia Dini 4 (2): 892-99. https://doi.org/10.31004/Obsesi.V4I2.476.

Piaud, Program Magister, Fakultas Ilmu, Universitas Islam, and Negeri Sunan. n.d. "Pembuatan dan Penggunaan Media Big Book Membaca Atik Latifah Yang Diantaranya Adalah Nilai Agama Dan Moral , Sosial Emosional, Fisik" VI: 141-55.

Saepudin, Encang, Sukaesih Sukaesih, and Agus Rusmana. 2017. "Peran Taman Bacaan Masyarakat (TBM) bagi Anak-Anak Usia Dini." Jurnal Kajian Informasi \& Perpustakaan 5 (1): 1-12. https://doi.org/10.24198/JKIP.V5I1.10821.

Samiaji, Mukhamad Hamid, Imam Hidayat, and Safinatun Najah. 2021. "Manajemen Strategi Dalam Pengembangan Mutu Pendidikan Anak Dini." Jurnal Pelita PAUD 5 (2): 18492.

https://doi.org/10.33222/PELITAPAUD.V5I 2.1290 .

Sari, Dianti Yunia. 2017. "Peran Guru Dalam Menumbuhkan Literasi Melalui Bermain Pada Anak Usia Dini." Golden Age : Jurnal Pendidikan Anak Usia Dini 1 (2). https://doi.org/10.29313/GA.V1I2.3316.

Suwandi, Sarwiji. 2019. Pendidikan LiterasiNo Title. Bandung: Remaja Rosdakarya Offset.

"View of Peningkatan Kemampuan Membaca Anak Melalui Permainan Melengkapi Huruf Menjadi Kata." n.d. Accessed October 12, 2021.

http://jurnal.upmk.ac.id/index.php/pelitapaud /article/view/230/168.

Wigati, Mukti, and Novan Ardy Wiyani. 2020. "Kreativitas Guru Dalam Membuat Alat Permainan Edukatif Dari Barang Bekas." AsSibyan: Jurnal Pendidikan Anak Usia Dini 5 (1): $\quad 43 . \quad$ https://doi.org/10.32678/assibyan.v5i1.2700.

Yansyah, Yansyah, Jamiatul Hamidah, and Lita Ariani. 2021. "Pengembangan Big Book Storytelling Dwibahasa Untuk Meningkatkan Literasi Anak Usia Dini." 
Implementasi Program Pengembangan....

Triyanal Raden Rachmy Diana²

P ISSN 2548-6284 E ISSN 2615-0360

Vol. 6 No. 1 Desember 2021

Jurnal Obsesi: Jurnal Pendidikan Anak Usia Dini 6 (3): 1449-60. https://doi.org/10.31004/OBSESI.V6I3.1779

Yunus, Syarif. 2020. “Budaya Literasi Masyarakat
Indonesia Rendah, Inilah 6 Dampak Mengenaskan." 2020 https://kumparan.com/syarif-yunus/budayaliterasi-masyarakat-indonesia-rendah-inilah6-dampak-mengenaskan-1tTiZc5cDeT. 